\title{
H. P. LOVECRAFT ON SCREEN, A CHALLENGE FOR FILMMAKERS (ALLUSIONS, TRANSPOSITIONS, REWRITINGS)
}

\author{
Gilles Menegaldo \\ Université de Poitiers \\ gilles.menegaldo@univ-poitiers.fr
}

Recibido: 11-03-2019

Aceptado: 30-03-2019

\section{AbSTRACt}

This article first delineates the reasons why it is difficult to adapt Lovecraft's fiction to the screen. It then analyses different types of adaptation, either straight or more loose, focusing in particular on the work of Stuart Gordon, one of the main adapters of Lovecraft with films ranging from parody (Herbert West Reanimator) to more serious adaptations which however depart in various ways (especially adding women characters and sex) from their source text (Dagon, The Dreams in the Witch House). Andrew Leman's The Call of Cthulhu, a pastiche of early silent films, provides a good example of straight adaptation. It also proves rewarding to compare two different retellings of the same novel, The Case of Charles Dexter Ward, by two directors, Roger Corman (The Haunted Palace) and Dan O'Bannon (The Resurrected). Corman tends to associate Poesque Gothic and Lovecraft while O'Bannon uses film noir conventions, also setting the story in a contemporary context. Lastly this article analyses the presence of Lovecraftian themes and motifs in films that are not adaptations like Alien or the Quatermass trilogy. A case in point is John Carpenter's apocalyptic trilogy that provides a convincing re-appropriation of Lovecraft's fictional universe.

KEYWORDS: adaptation, genre conventions, hybridity, myth, terror and horror, fantasy, dreams, cosmic monsters, parody, reflexivity. 
RESUMEN

En primer lugar, este artículo describe las razones que hacen difícil adaptar la ficción de Lovecraft a la pantalla. A continuación, se analizan diferentes tipos de adaptación, ya sea estricta o más o menos libre, centrándose en particular en el trabajo de Stuart Gordon, uno de los principales adaptadores de Lovecraft con películas que van desde la parodia (Herbert West Reanimator) hasta versiones más serias, que, sin embargo, toman diversas vías (en especial, agregando personajes femeninos y sexo) a partir de su texto fuente (Dagon, The Dreams in the Witch House). The Call of Cthulhu, de Andrew Leman, un pastiche de las primeras películas mudas, es un buen ejemplo de adaptación estricta. También resulta gratificante comparar las diferentes versiones de la novela El caso de Charles Dexter Ward que realizaron dos directores, Roger Corman (The Haunted Palace) y Dan O'Bannon (The Resurrected). Así, mientras Corman combina la dimensión gótica de Poe con Lovecraft, por su parte, O’Bannon usa las convenciones del cine negro y sitúa la historia en un contexto contemporáneo. Finalmente, este artículo analiza la presencia de temas y motivos de Lovecraft en películas que no son adaptaciones, como ocurre en Alien o en la trilogía de Quatermass. Un ejemplo de ello es la trilogía apocalíptica de John Carpenter, que ofrece una reapropiación convincente del universo ficticio de Lovecraft.

Palabras Clave: adaptación, convenciones de género, hibridez, mito, terror y horror, fantasía, sueños, monstruos cósmicos, parodia, reflexividad.

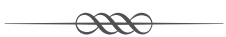

HP Lovecraft was not very fond of cinema as testify some remarks in his letters. He shows some contempt for the nascent medium (like other writers of his time, for example Virginia Woolf). Even three days before his death, he speaks of «the utter and unrelieved hokum of the moving picture». He disliked even Tod Browning's Dracula and Karl Freund's The Mummy (despite his fascination for Egypt) on account or their lack of fidelity to the source work. He had a rather narrow conception of filmic adaptation as shows this statement: «Generally speaking, the cinema always cheapens and degrades any literary material it gets hold of - especially anything in the least subtle or unusual». ${ }^{1}$ He states in a letter to Robert Barlow: «I saw the cinema of Frankenstein and was tremendously disappointed because no attempt was made to follow the story». Yet he also adds: «However, there have been many worse

1 H. P Lovecraft to R. H. Barlow, in Joshi (1996: 581). 
films and many parts of this one are really quite dramatic when they are viewed independently and without comparison to the episodes of the original novel» (in Joshi, 1966: 581). He would have been horrified at viewing some adaptations of his stories.

Yet Lovecraft did go to the movies fairly often, especially during his stay in New York and seems to have enjoyed a few films that appealed to his imagination and dealt with mythological subjects. He regretted not having seen The Cabinet of Dr Caligari (the insanity motif is important in his fiction), he was thrilled by The Nibelungen (Fritz Lang), expressed his fascination towards films with spectacular sets or special effects like The Lost World (Harry Hoyt, 1925) and was also struck by the performance of Lon Chaney in The Phantom of the Opera (Rupert Julian, 1928) as testifies this letter: «What a spectacle it was! Horror lifted its grisly visage and I could not have been made drowsy by all the opiates under heaven! Ugh!!! The face that was revealed when the mask was pulled off» (in Joshi, 1996: 365).

If Lovecraft is not enthusiastic about cinema, the filmic medium is faced with some problems when putting his work on screen and most adaptations have modified considerably the source material to fit the expectations of the audience. We should also distinguish between straight adaptations, re-adaptations, rewritings (often associating several sources and mingling several genres) and re-appropriations of Lovecraftian themes and concepts in films that are not adaptations. Thus we will discuss first various types of adaptations then we will focus on two re-adaptations of the same story (The Case of Charles Dexter Ward) and will end with an evocation of some re-appropriations, namely the Quatermass series and John Carpenter's apocalyptic trilogy.

WHY IT IS DIFFICULT TO ADAPT LOVECRAFT?

Lovecraft's fiction offers a rich imaginary world which could provide a good material for filmic transposition: mysterious objects, forbidden secrets, adventurous explorations of the Australian desert or Africa, discovery of horrors at the heart of modern cities, investigative and initiatory quests, metamorphoses, scenes of blasphemous, shocking revelations, questions of identity, blurring of the frontiers between dream and reality, paroxysmic states of consciousness, alien beings, cosmic monsters, etc. However, there are relatively few successful adaptations and many flawed films. 
A first reason may be Lovecraft's peculiar conception of what should be a true «weird tale». In a letter to Catherine L. Moore in 1935, he defines his approach:

The hero of such a story is never a person, but always a phenomenon or condition -the punch or climax is not what happens to anybody, but the realization that some condition contrary to actual law as we understand it has (fictionally) had a brief moment of existence. For the object of weird fiction is purely and simply emotional release for the very small group of people whose active and restless imaginations revolt against the relentless tyranny of time, space and natural law (Lovecraft, 1976: 157-158).

Thus both characters and events are secondary in regard to atmosphere or mood, which raises a problem for screen adaptation.

Another aspect is Lovecraft's philosophical stance: pessimism and nihilism. Beyond the veil of reality, there is something threatening, coming from outer space or another space-time continuum or already there (buried in the depths of the ocean or the desert sands or the frozen immensities of the North Pole) which makes our world nightmarish. In that cosmic perspective, man is thus an insignificant creature that fails to understand the mysteries of the universe and becomes insane when he tries. As Lovecraft states in «The Call of Cthulhu»: «The most merciful thing in the world is the inability of the human mind to correlate all its contents. But someday the piecing together of disassociated knowledge will open up such terrifying vistas of reality that we shall either go mad from the revelation or flee from the deadly light into the peace and safety of a new dark age» (Lovecraft, 1991: 125).

Thus man is rarely a hero in his fiction and barely a character to identify with, merely a prop. Michel Houellebecq speaks of the «futility of all psychological differentiation»: «His characters no longer required it. All they needed was functional sensory equipment. Their sole function, in fact, would be to perceive. It might even be said that the deliberate banality of his characters contributes to reinforcing the compelling nature of Lovecraft's universe» (Houellebecq, 2005: 68).

This approach of character raises some problems for a Hollywood producer as the almost complete absence of women characters and erotic elements (only abject matings between female humans and entities) and consequently the lack of love interest. Thus the conventional elements of the horror film plot (sex, violence, suspense) are almost absent from Lovecraft's fiction. Hence we do have a frequent addition of female characters in most adaptations. 
The abstract character of some texts, the lengthy descriptive passages, the convoluted syntax, does not favour the adaptation process. Lovecraft's ideological stance, his xenophobia and racist statements may raise some problems for producers. His teratological pantheon, non-Euclidean geometry, cyclopean architecture and cosmic threat, also require sophisticated special effects.

While Lovecraft avoids, by using suggestion or a rhetoric of the implicit and the unnameable, a graphic representation of the monster or alien entity, cinema must at some point, show the monster even if this revelation is delayed. Because of the complex hybrid nature of these entities, the film must have a relatively big budget to avoid grotesqueness. John Carpenter states: «Once you start reading it, you realize it is in his language. He describes things that are indescribable, the indescribable horror. Some of his best stories are just impossible to visualize» (in Mitchell, 2001: 7). Even with digital technology, it is still an aesthetic challenge to feature entities defined by features pointing to the impossibility of representation: viscosity, inconsistency, hybridity, multiplicity. No discernible shape is accessible to the observer who loses his rational landmarks and risks insanity. When he attempts to depict in details monstrous entities, the narrator often uses artistic representation: frescoes, bas-relief, paintings. This recourse to the mediation of objects betrays the limits of representation and leads to a reflexive discourse. Lovecraft writes: «It would be trite and not wholly accurate to say that no human pen could describe it, but one may properly say that it could not be vividly visualized by anyone whose ideas of aspect and contour are too closely bound up with the common life-forms of this planet and of the three known dimensions («The Dunwich Horror»; Lovecraft, 1991: 243-244).

\section{AdAPTATIONS}

Linda Hutcheon defines adaptation as product but also as a process of «intertextual palimpsestuous transformation». She rejects the notion of fidelity to the source text and privileges autonomy: «Perhaps one way to think about unsuccessful adaptations is not in terms of fidelity to a prior text, but in terms of a lack of the creativity and skill to make the text one's own and thus autonomous» (2006: 20).

The first attempts at adapting Lovecraft take place in the sixties, 20 years after the writer's death. Roger Corman offers in 1965 a first version of The Case of Charles Dexter Ward, under a Poe title, The Haunted Palace, so as to 
integrate this film in his Poe Cycle. Other films will follow, like The Shuttered Room (David Greene, 1966), or The Dunwich Horror (Daniel Haller, 1969), which uses psychedelic special effects and subjective camera work to convey a sense of cosmic exteriority. A fashion for Lovecraft is expressed in the eighties in the parodic, gory films of Stuart Gordon or those, tamer and less inventive of Brian Yuzna who teems with Christophe Gans and Shusuke Kaneko to direct The Necronomicon (1993). More recently there has been a wave of Lovecraftian adaptations, partly in the wake of the H.P. Lovecraft film festival, created in 1996 and held in Portland. We will focus on some of these adaptations, starting with Stuart Gordon, one of the foremost Lovecraft adapters with both feature and short films, big budget and independent productions, serious adaptations or parodies.

In 1985, Stuart Gordon directed Re-Animator, a slapstick horror, gory adaptation of Lovecraft's episodic story, «Herbert West Reanimator» (1922), meant by the writer as an ironic retelling of the Frankenstein myth. A maniacal and obsessive doctor manages to raise the dead and is eventually torn apart by his zombie like creatures, like Dr Moreau in H.G. Well's novel. Gordon offers a story with campy undertones, with implicit reference to The Rocky Horror Picture Show (Jim Sharman, 1975) or Flesh for Frankenstein (Paul Morrissey, 1973). As Rick Worland states: «Re-Animator encapsulates more than a century of horror tradition. Its production design juxtaposes bold, saturated colours with the genre's typically shadowy, high contrast lighting, most notably in syringes of mad doctor West's bright yellow-green reagent glowing against black backgrounds, a look that evokes both post-war science-fiction laboratories and four-color comics» (2007: 244).

His Herbert West owns all the attributes of the Lovecraftian character: a juvenile, frail physique and an excessive hubris, which urges him to go beyond human limitations and knowledge in order to transgress the frontier between life and death. Events that are spread over several years in the source text are condensed within a month (ellipses keep up a veil of uncertainty). A chain of events leads to West's dismemberment by his living-dead victims, while he himself only kills once (contrary to the short story where reluctant subjects are murdered).

Gordon instils some comedy in this orgy of blood: slapstick (neutralizing the reanimated cat in the cave) and the un-Lovecraftian love triangle with Dr Hill, Daniel and his bride Meg (Barbara Crampton). Dr Hill lusts for Meg, which leads to her kidnapping and the Grand Guignol scene that gave its reputation to the film: Dr Hill holds his own severed head, trying to caress 
Meg. Later, Daniel and Herbert enter the morgue in order to test the serum on a human corpse. Dr Halsey, Dean of the medical faculty of Miskatonic arrives at the morgue at the wrong moment. He is killed by the living corpse then reanimated by West as a raving lunatic who will eventually be lobotomized.

West's demise and death is close to the textual end where he is carried away by his former victims led by a headless living dead. In the film, West who has come to the morgue to recuperate his serum, surprises Dr Hill intent on practising cunnilingus on Meg, an acme in the grotesque of the film. Philippe Rouyer speaks of the inversion of the taboo of necrophilia as the dead rapes the living. Then, West is assaulted by the living corpses controlled by Hill. As he attempts to kill Hill by injecting him a massive dose of serum, he is caught up in the intestines of Hill, which carry him in a dazzling white light to the beyond.

In 2001, Stuart Gordon directed Dagon, mostly an adaptation of «The Shadow over Innsmouth» rather than the title story. The action is set in a contemporary context in the small Spanish harbour of Imboca. The first images of the inhabitants are furtive and disquieting: a strange face behind a closing shutter, bent, shuffling silhouettes, weird low voices. Moreover the inhabitants' physical blemishes are developing (they are born human then mutate), which enables Gordon to exhibit differentiated hybrid monsters and thus to increase the spectator's discomfort, by foregrounding images of abjection and impurity which parallel degenerative diseases. The village seems fixed in a past time, without modern appliances (old cars and telephones), contrasting with the attributes of modern life like Barbara's cell phone, which is ineffective. Symbolically Paul, the male hero's computer is thrown overboard from the outset. Contrasting colours express that dereliction: drab (black, greyish and greenish) for the inhabitants and vivid for the protagonists who are thus easily spotted and pursued.

By means of a more and more graphic exhibition of supernatural elements, Gordon shifts the mood of his film from the uncanny (the inhabitants do not wink, the face of a fisherman is oddly motionless behind his dark glasses) to the fantastic (the priest's hands are webbed and the slits on the neck of the hotel keeper will prove to be gills). The story turns to the horrific with the discovery of monstrous specimen and of tanned human skins to serve as masks for the hybrid denizens of the harbour. The flashback narrative of Ezekiel (Zadok Allen in the text), the drunken old man, confirms the existence of the fishmen or frogmen. The film drifts into weird fantasy and adds an erotic touch when we meet Uxia first seen in a dream. This beautiful, seductive and 
cruel princess, part octopus, part woman, reminds us of the female heroines (victims or femmes fatales) on the covers of Weird Tales or Amazing Stories. Gordon also adds scenes of sadistic violence and torture, including the ritual sacrifice of the naked Barbara who is thrown into a pit and promised to the fish god, elements that are absent from the source text.

Physical dereliction is emphasized as well as the decay of place. Gordon manages to convey the mood of the story, in particular images of the sinister harbour, the empty, dirty, squalid streets full of rubble, detritus, the hybrid entities hiding behind closed shutters in decrepit buildings with damp soiled walls and dirty smelly bathrooms as in the hotel where Paul March finds a temporary refuge. He then discovers his true origin adumbrated in the premonitory dream sequence that opens the film and confirmed by the starting of his transformation, gills opening on his body. The fragile, objective link that separated rationality from the irrational is definitively broken and the nature of the following events is on the side of the supernatural and fantasmagoria. Paul was until his meeting Uxia confronted with a degenerate but still human population while after their encounter, doubt is no longer allowed. The Imbocanos are hybrid, telepathic beings who worship a more alien creature, an extreme form of otherness. Gordon then shows explicitly submarine monsters, sacrificial rituals, the way Dagon the octopus god preys upon women, drawing them to the depths of the ocean. He can also reveal the true identity of the hero and the story of his origin in a mythical narrative validated by the progressive disclosure of information. In 2005 Gordon also directed a one hour adaptation of The Dreams in the Witch House, part of a TV anthology entitled Masters of Horror.

\section{THE NECRONOMICON}

The Necronomicon freely adapts the Lovecraftian universe with 3 short pieces linked by a frame narrative where Lovecraft (Jeffrey Combs), in search of inspiration, introduces himself in the vaults of a library (guarded by strange monks) in order to read the Necronomicon, which inspires him 3 stories he scribbles frantically on his note book. The three narratives are in fact rather remote from the original text. Gans in «The Drowned» very loosely adapts «The Rats in the Walls». It stages an experiment aiming at reviving the dead fiancée of the hero Edward de La Poer thanks to the magic formulas in the Necronomicon. The film relies on a flashback structure, which sets a parallel between De la Poer and his ancestor. The latter tried to resurrect his wife and 
daughter drowned in a shipwreck. He is confronted with hybrid submarine entities and commits suicide. The descendant reiterates the experiment but the beloved one returns in the shape of a hybrid entity with a human face, and a tentacled body betraying her origin, as a prelude to the surging of the great Cthulhu. The special effects, due to a scanty budget are rather coarse and do not match Gans' ambition who proves inventive in frame composition and editing, playing also with a mobile camera set on a crane, allowing spectacular angles. «The Cold», adapted from «Cool Air» stages a newspaper man who inquires upon a series of murders in a district of Boston and discovers thanks to a witness, the secret of Dr Madden, a mad scientist who extracts from his victims a fluid which enables him to prolong his life in a refrigerated space. This segment contains a framed narrative and offers several twists and some spectacular moments. It also benefits from the talent of the remarkable David Warner. Lastly «Whispers» starts as a detective story, then drifts into splatter horror and stages a race of alien beings who feed upon the blood of their victims but also invade their psyche as in «The Whisperer in Darkness». The film is full of rather poor horrific special effects but features a couple of sadistic average American citizens and illustrates the Lovecraftian idea of the survival of alien entities in the depths of a modern metropolis. The ruined ancient city borrows its architectural design from Maya culture.

This tryptic suffers from the lack of financial means (limited shooting time, B film conditions and budget). Gans' film fares best thanks to its competent editing and its references, both thematic and stylistic, to the Hammer films, those of Roger Corman and devices used in Japanese ghost films. The filmmaker confesses that his major influence is poesque - the fascination of female beauty linked to death, the concept of return from the dead - rather than Lovecraftian.

An Example of Straight Adaptation: The Call of Cthulhu (ANDREW LEMAN, 2005)

This independent film is one of the most convincing recent adaptations, contradicting the idea that one needs a big budget to adapt Lovecraft. This 46 min. movie is black and white and silent, a pastiche of 1920's expressionistic films, with numerous inter-titles, which enable to follow a rather complex plot and also quote from Lovecraft's text. The film takes up the main events of the source text and adopts its embedded narrative structure, adding a prologue and an epilogue. 
The film opens on the revolving shot of a jigsaw puzzle that represents a famous Van Gogh's painting, The Starry Night. The anonymous narrator, pent up in a psychiatric asylum asks his lawyer to destroy documents inherited from his great uncle. Confronted with the hesitation of his interlocutor, he tells him the story of the investigation led by this great uncle about a mysterious cult. He has gathered a file made of several documents, testimonies either written or drawn and objects (the sculpture of a mysterious tentacled entity) as clues. Leman thus follows Lovecraft's plot, using flashbacks for each secondary narrative, but also double exposure to show letters, press cuttings, diagrams, personal diaries, sea maps, sailors' log etc. The film stages the testimony of Henry Wilcox, a young sculptor haunted by dreams of an ancient city, then that of Inspector Legrasse who was the witness of a strange ceremony in Louisiana (evoked by one of the cultists, the half-breed Castro), lastly that of Johansen the sailor the only eye-witness of the catastrophe who before his death consigned the events in his diary given to his wife. The professor reads in this diary, which is converted into images, the discovery on an uncharted south sea island of R'lyeh, a sunken cyclopean city from where emerges Cthulhu, a cosmic entity which kills the sailors or drives them into madness and then pursues the ship. If the incarnation of Cthulhu, a plastic puppet animated in stop-motion, is unconvincing, the film offers a close rendering of the short story's narrative set up, mood, and substance. The image plays upon expressionistic contrasts and uses projected shadows efficiently. Shots are well composed, mostly close shots on the faces of the witnesses (reaction shots) and slanted images. Leman emphasizes expressiveness, using heavy make-up and low-key lighting. The sets are the result of a «bricolage» to quote Genette, made mostly of cut out papers and plastic and they acknowledge their artificiality. Digital technology serves to integrate all kinds of images. The non-Euclidean character of the architecture of the city is rendered by means of forced perspective, trompe-l'œil effects and extreme camera angles. Mirror tricks are also used. The sequences animated in stop-motion are rather crude but they pay a tribute to such creative artists as Willis O'Brien and Ray Harryhausen. The same approach and technique is used by Sean Branney, co-author of The Call of Cthulhu for The Whisperer in Darkness (2011), also distributed by the H. P. Lovecraft Historical Society. Among recent films, we must mention Die Farbe (Huan Vu, 2010), a rather convincing adaptation of «The Colour out of Space», but we will now focus on two adaptations of The Case of Charles Dexter Ward: The Haunted Palace (Roger Corman, 1965) and The Resurrected (Dan O'Bannon). 
Roger Corman's Edgar Poe's Haunted Palace adopts the title of a famous poem by Poe (in «The Fall of the House of Usher»), but the film is actually an adaptation of The Case of Charles Dexter Ward. Even if the credit sequence mentions, «from a story by HP Lovecraft» without quoting the title and aims at exploiting Poe's reputation, the script follows closely Lovecraft's plot. The text relies on a dual time frame: the occult activities of the witch Joseph Curwen in the 18th century, his arrest, public trial and execution and his reincarnation a century later. Corman limits the historical episode to the opening sequence that stages the beginning of a ritual aiming at conjuring up the ancient gods. This ritual, which consists of delivering to a monstrous entity a young woman in a state of hypnosis, is interrupted by infuriated villagers. The scene ends on the burning alive of the witch who before dying extends his curse to the whole community. The modern plot is situated 110 years later, towards 1850. Charles Ward, Curwen's descendant comes back to the village to take possession of the castle he has inherited. There is a striking likeness between Curwen and Ward (Price plays both parts) and the villagers, still submitted to the curse are convinced of Curwen's return, which the narrative will confirm by means of the portrait motif (as in the text). In the film, Curwen's portrait is a fantastic object, used by the spirit of the dead sorcerer in order to invest the psyche of his descendant. When Ward and his wife Ann (an added character) enter the gothic mansion, what they see first is the portrait, at the back of the frame, but radiating light. Ann Ward notices the uncanny resemblance with her husband, exclaiming: «Charles it's you! It's absolutely fantastic». The portrait is set upon the chimney, which confers the object a spatial superiority. Several confrontations between Ward and the portrait punctuate the film, partaking of the bewitching power of the portrait filmed in close up. Psychic appropriation is conveyed by the shot reverse shot editing, opposing shots of Ward's face in high angle and close ups on the painted face of Curwen, with intense, burning eyes, filmed in low angle. The psychic power is stressed by Ward's fascinated face, constant and erratic changes in his behaviour and decisions. His voice becomes more imperious, authoritative, less modulated by softer inflexions in tone.

This shift of behaviour creates an uncanny feeling which triggers a fantastic effect which is reinforced by the introduction of a voice over which seems to emanate from the portrait. The low raucous voice is associated with close shots and zooms on the portrait during the confrontation. A dialogue is 
stablished between Ward and the portrait. The uncanny effect is emphasized when the witch's spirit enters Ward's body. We start from a backward tracking shot on the portrait enabling Ward to enter the frame. Another tracking shot closes on Ward's face whose expression has changed. The transfer is also expressed by means of a shift in colours. Curwen's face turns greenish, which links him to a corpse but also relates him to evil and the diabolical, even if it is not the devil that is invoked, but the older gods who want to come back to earth thanks to couplings with human beings, a task that Curwen has assigned himself.

After taking revenge from the villagers, Curwen resurrects, by means of ritual incantations, his mistress, Esther Tillinghast, and he uses Ward's wife as a bait to contact entities. The film closes on the invasion of the castle by villagers equipped with torches and the liberation by Dr Willett of Ward and his wife. The evil portrait is burnt which suggests Curwen is vanquished, but the last shot of the film frames Ward whose greenish face and imperious voice suggests the spirit of the witch is still active in Ward's body. Corman integrates references to other Lovecraft texts, in particular «The Dunwich Horror», staging mutant monstrous villagers, victims of Curwen's experiments. While Poe privileges psychic interiority and anthropocentrism, Lovecraft opens on a cosmic threat, which erases the importance of human presence. The film ends on the disquieting look and smile of the man who pretends he is Charles Ward. Man remains the spring of fear, not otherworldly monstrous creatures. Corman's film thus differs from Lovecraft's stance. If Michel Houellebecq underlines the accuracy of Lovecraft's descriptions, it is to contrast with the impression of limitlessness strikingly surging up and stressing the idea of a scale discrepancy, which contributes to minimize all human existence. Corman still refers to a Poesque conception of human evil rather than highlighting cosmic evil.

Julian Petley (2007) mentions Ann Ward's oneiric wanderings through the haunted gothic palace, defined as a Lovecraftian locus. However these nightly displacements remain confined within a house whose architecture is conceived by man. Conversely in Lovecraft's novel, Dr Willett's wanderings in the subterranean vaults of Joseph Curwen's laboratory lead the reader into an uncanny threatening space where man loses control. Even if he stages a diabolical character, Corman never questions man's status and position and his dramatic space is strongly structured by the towering presence of the gothic castle, an objective correlate of Curwen's potent mind that overpowers the villagers. More than the corridors where the heroine wanders, we are struck by the gi- 
gantic staircase leading to the cave where innocent victims are sacrificed to the otherworldly creature held at the bottom of the well. This long flight of steps is all the more conspicuous as it appears in a shot whose asymmetric composition reflects the mental unbalance of the main protagonist.

Corman also takes up Poesque archetypes emphasizing female characters absent in Lovecraft, Esther the dead mistress Curwen manages to resurrect and Ann Ward, under threat of the witch who seeks to replace her husband and appropriate her body. Corman stresses the victimization of his heroines as testifies the scene where Ann, walking through the dark corridors of the castle is caught in a gigantic spider's web. As she faints, the ominous silhouette of a servant looms in the darkness. Corman displaces Lovecraft's return motif, «poétique du revenir» according to Helene Cixous (1972), foregrounding not the intellectual curiosity of the malevolent ancestor seeking to question the dead and appropriate their knowledge but rather his romantic longing for recapturing love beyond death (as in «Morella» or «Ligeia»).

If Corman succeeds in this poesque evocation, he fails indeed when he tries to convey an idea of Lovecraftian cosmic otherness. Even though Corman shows the monstrous entity Yog-Sothoth only briefly and almost out of focus, he cannot visually express the sense of dread typical of the sublime effect and this fleeting vision cannot convey a paroxysmic moment of pure terror. It is mostly through sound effects that the director conveys a feeling of terror. As Christophe Chambost (2017) states: «When the monster fleetingly appears, Ann's cries are mingled with the low roaring of the creature, the metallic grindings of the railing and the low hammerings of the musical score» (my translation). The aggressiveness of the soundtrack evokes the deregulation of the sensory perceptions typical of Lovecraftian fiction. Despite these shortcomings, Corman manages to illustrate a major Lovecraftian motif, that of the possession of the human psyche by a superior force, coming from a remote past of from cosmic outsidenesss, as in The Shadow out of Time. The excess of Curwen's experiments is more forcefully staged in The Resurrected.

Dan O'Bannon's remains closer to the source text than Corman in some respects. He highlights the story of Curwen's resurrection thanks to alchemy and science, but tones down the part played by Curwen's portrait, contrary to Corman who insists on its malevolent influence. O'Bannon keeps up the circular structure of the story, starting by the reference to Ward's escape from the lunatic asylum and ending on that so-called escape. The film is also closer to the text as it stages the various phases in the investigation of the case and dramatizes in particular the horrifying discoveries in Ward's subterranean se- 
cret laboratory. The film, like the text, lays stress on the gradual physical and mental degradation of Charles, even quoting from the text when Ward accounts for his ill heath by the mephitic emanations from the river. Numerous details are kept, including names of characters like Dr Allen or Luke Fenner, locations like the Pawtuxet farm, the presence of howling dogs, the reference to awful smells and noises. The motif of vampirism, present in the text, is clearly emphasized in the film. O'Bannon also keeps the time structure (though he simplifies it) with a series of flashbacks, including a historical episode narrated in the diary of Ezra Weeden discovered by chance and taking place in the $18^{\text {th }}$ century at the moment of Curwen's demise by a crowd of angry citizens, after some macabre discoveries in the river.

However there are many important changes. First, the story is set in a modern context and no longer in the twenties. It is narrated in the first person and not by an anonymous narrator. Also while Ward's story in the text extends over a period of ten years (from 1918 to 1928), it is condensed within 3 weeks in the film, which makes the narrative less verisimilar as when the investigator discovers by chance a manuscript in a suitcase. Another major change is that it is no longer Dr Willet, an intimate of the Ward family who investigates the case, but a private detective hired by Claire, Ward's wife. Like Corman, O'Bannon adds a woman character who does not feature in the text and he also makes of Charles Ward, a young student of occultism in the novel, an older, more mature character, an expert in pharmacology.

The film adopts some of the conventions of the film noir. The private detective, John March ${ }^{2}$ becomes the major character and the narrator (in voice over) of the story, hence the subjective colouring of his account. Claire is also an important character, more as a victim than a femme fatale even though the film adds a touch of romance that is never actualized, except in a dream. She is also the one that tells the story of her husband's growing insanity. Dr Willett disappears completely and his part is very partially taken up by Drs Waite and Lyman, (who also feature in the novel as alienists). However, as is stated by Chambost, they are no longer related to insanity or occultism, but «deliver pointed diagnoses on metabolism, the respiratory, cardio-vascular system or the hormonal dysfunction of Ward/Curwen, thus increasing the rational discourse of the narrative» (Chambost, 2007; my translation).

Ward's account of his research is more scientific than occult and all this scientific metadiscourse tends to downplay the alchemical and occult quality

2 This name reminds of the hero in «The Shadow over Innsmouth». 
of Ward's experiments. However, O'Bannon does not fully dispense with the occult practices displayed in the novel and the remains of the alchemist and cabalist, Nicholas Flamel and Robert Fludd are preserved in urns that are visible in Curwen's underground laboratory in the long sequence of exploration led by a party of three (while Willett is alone in the text). O'Bannon shows the urns containing the ashes of famous men and stages, as in the novel, the spectacular effects of the «essential salts». He also shows what happens when an alchemical reagent is poured over the bones of the deceased Curwen, enabling the witch to return to life under the mask of bearded Dr Allen. Theatrical scenes display the monstrous entities that are the products of these experiments and are an echo to the excessive nature of the story and the hyperbolic style of the writer. O'Bannon insists on the one hand on the terrifying darkness which envelops the protagonists in the underground labyrinth leading to Curwen's laboratory, on the other by hiding nothing of the unfinished monstrous creatures issued from disastrous experiments. He even takes up the textual motif of the dropped lamp and the difficulty to lighten the place. While Lovecraft only hints at the monstrously hybrid, unfinished appearance of the failed experiments, stressing mostly the sounds coming from the various pits of darkness, O'Bannon actually shows these creatures (reconstituted from their remains), at least fleetingly, by means of a combination of puppetry and stop-motion. The monstrous mouth of the creature found in the river is particularly suggestive while the special effects of the last scene of confrontation between March and Curwen are less convincing, due to an excess of pyrotechnics, bluish and pinkish lights.

The shift from abstract to concrete, from intellectual terror to organic horror can be felt in one of the last assertions of the alchemist: «Strong as my hunger for knowledge may be, my hunger for food is so much stronger!». Indeed the blood motif is quite amplified. In the novel it is implied that some of the hybrid, creatures that are conjured up consume human flesh. In the film, Ward himself (or rather Curwen) turns cannibal. When caught in a straitjacket, he demands fresh blood from Dr Lyman, the woman psychiatrist. During the final confrontation, while Curwen is intent on devouring March, he admits his victory will be complete when acquiring a new set of teeth to substitute himself for Charles and possess his wife. ${ }^{3}$ Curwen's last remark underlines the danger linked to destructive orality and shows him as a sexual predator as in Corman's film. This sexual motif has little to do with Lovecraft,

3 «Mrs. Ward will be pleased, yes... especially when my teeth are fixed!». 
but is quite frequent in filmic adaptations. Moreover, $\mathrm{O}^{\prime}$ Bannon adds relations of seduction (and male sexual desire) between the two heroes, the detective and his beautiful client. John March's nightmare associates a fantasized kiss and horror (a scene of torture, an eye operation, a shattered corpse). The end of the dream shows Claire transform into a hideous corpse (possibly a tribute to The Shining). The use of quick editing, of wide angled shots, of a circular movement of the camera that upsets the order of things, the mingling of love and horror, the presence of a pervading illustrative musical score, all this leads to a sense of «carnivalesque inversion» (cf. Chambost's analysis).

The degradation of the human race is central in Lovecraft's fiction in which monstrous heredity transforms the characters like Ward into submissive objects. In O'Bannon's film (as in the text), Ward's death is only revealed in the last part. However the director warns us early of his fate when he shows in close up a copy of Goya's painting Saturn devouring his sons in Ward's first laboratory. The painting surges up again in March's nightmare, suggesting an analogy between Saturn the God of Time devouring his sons and Curwen who feeds on his descendant. Goya's painting plays an important part, superseding Curwen's portrait that is not felt as an evil, almost sentient presence.

O'Bannon's ending is even more pessimistic than Lovecraft's where there is at least a sense of evil being eradicated and the world purified. Curwen's destruction brings less hope to the spectator. As Chambost states: «The detective's final remark underlines the loss of belief in fundamental humanist values». ${ }^{4}$ Willett is in fact presented in the text as stronger willed than March. In both works however, evil conveys a sense of power, transcending time, space and bodily limitations, which highlights man's relative insignificance.

\section{LOVECRAFTIAN MOTIFS IN NON ADAPTATION FILMS}

Alien is clearly influenced by Lovecraft, with its script by Dan O' Bannon and its designs by H.R. Giger, also an admirer of the writer to who he pays homage in his biomechanical series of paintings, Necronomicon. In Guillermo del Toro's Hellboy (2004) a monstrous cosmic entity, Ogdru Jahad, tries to escape from a crystal prison where he has been lying for thousands of years. Italian horror cinema has also made an extensive use of Lovecraftian motifs, in particular Lucio Fulci's Paura nella città dei morte vivanti set in Dunwich and

4 «I made it look like Charles had escaped. I wanted to spare [Claire] the truth... Pfff.... The truth... Whatever that means». 
quoting from «forbidden books», but we shall focus on 2 examples: the Quatermass series (briefly) and John Carpenter's apocalyptic trilogy.

\section{The Quatermass Series and Genre Hybridity}

In the Quatermass series produced by the Hammer studios, the main character, Bernard Quatermass, head of the British Experimental Rocket Group, has to fight an alien threat from outer space. As the serials develop, danger looms closer and closer. In the first story, The Quatermass Xperiment (Val Guest, 1955), the invading entity is brought back from space. After his escape from hospital, the surviving astronaut gradually mutates into a monstrous organism, half-plant half-animal, leaving a slimy trail of death and destruction. This reminds of the «Colour out of Space» where human beings in contact with a strange meteorite undergo strange metamorphoses. In the second, Quatermass II (Val Guest, 1957), the alien is already there, lying in wait in a gigantic factory stolen away from the government. The true nature of the aliens is revealed at the end: they are monstrous shapeless organisms, rather close to the lovecraftian shoggoths. In the third film, Quatermass and the Pit (Roy Ward Baker, 1967), the entity has lain dormant in the human psyche for five million years before being accidentally woken up. In other words, the threat evolves from an exterior force to one hidden not only among us but within us. In the first two films, Quatermass is instrumental in bringing the menace to the human planet (he sent the rocket in space; he unwittingly devised the means for alien creatures to survive on earth). In the third film, he is himself part of the danger. Indeed, apocalyptic doom grows uncomfortably close. By developing the idea of the impotence of the human race facing an enemy that came long ago from the stars (here planet Mars), the film is close to Lovecraft's recurrent idea of the puniness and insignificance of man. Even Quatermass now knows that he is part Martian. This film will inspire Carpenter for his remake of The Thing.

\section{The CARPenter's Trilogy}

Carpenter asserts his admiration towards Lovecraft and acknowledges his debt. Several of his films are inspired by Lovecraft's universe. The Fog (1980) conjures up Lovecraftian themes and motifs: the surging up of a legendary 
traumatic past, the omnipresent mist that recalls «The Strange High House in the Mist» and from which emanate malevolent and vengeful entities (the ghosts of the sailors, victims of the shipwreck) coming from oceanic depths.

The Thing (1982), a remake of Hawks and Nyby's film, stages an arctic space, icy and snowy, taking up the frame of «At the Mountains of Madness», the narrative of a scientific expedition who discover a city buried under the ice, strangely shaped fossils, then corpses of extra-terrestrial entities (the Old Ones). The scientists are finally confronted with protoplasmic monsters, the shoggoths. In Carpenter's film, a group of scientists discover the remains of a space ship and shelter a mysterious shape shifting entity, capable of incorporating animal or human organisms and taking up their physical appearance. Hence the paranoia that prevails in the group as any one becomes suspicious of the other's true identity. This entity recalls on the one hand the shoggoth, a physically unstable creature, on the other hand, the thing of cosmic origin that causes the degeneracy of vegetables, animal and human beings, following the fall of a meteorite in «The Colour out of Space».

The arrival of the Thing is shown in the first images, with the crash of the flying saucer. Carpenter's protoplasm is rather frightening: each part of the Thing is potentially autonomous and the organism incorporates its victims to imitate them in a form of devouring process at cellular level. Given time, the creature assumes full likeness with the model: appearance, intelligence, voice. A computer simulation made by the biologist indicates that if the Thing reaches a civilized zone, it would only need 27 hours to contaminate the whole world population.

As in Lovecraft's story, the narration is subjective. The main events are focalized by Blair the doctor, then McReady the pilot. The main interest is to convey a sense of paranoia that invades the team. All is based on the fact that from Bennings' first assimilation witnessed by Windows, anyone can be the Thing. The spectator never knows more than the characters (in Lovecraft the narrator knows everything, which is a major difference) and Carpenter even breaks the rule of character identification by casting doubt on McReady himself, suspected of being the Thing and staged very ambiguously, via a shot of the door slowly opened or almost zombified by the cold. We have to wait for Norris' reanimation (and the mythical sequence of transformation) in order to feel confident he is still human. In the final scene, two survivors are confronted but we wonder who is the Thing. While Lovecraft's protagonist comes back to civilization, Carpenter's hero seems condemned and so is humanity. Throughout the Apocalypse trilogy, Carpenter films fear: that of John Trent in In the 
Mouth of Madness, that of a group of students and of the priest in Prince of Darkness, and that of scientists in The Thing. A great number of shots at the close of sequences show terror on faces. After the neutralization of the various incarnations of the Thing (the monster in the dog kennel, the incineration of Bennings, the spidery head), but also following the various phases in understanding its behaviour, the close up on the fretful face of Blair, that is autopsy and computer simulation. This exhibition of fear partakes of the principle of the Lovecraftian narrative that chooses empathy by showing the effects of horror on the characters to who the spectator is linked by an identification process.

The Thing is original in its Lovecraftian approach because of its direct, frontal exhibition of the unnameable. If paranoia is the nodal point of the film, the unnameable is its focal point, at the centre of his aesthetic project. The choice of the title is revealing; the «Thing» is an entity that cannot be precisely defined. Here the unnameable is visible, yet still conceptually disturbing. The nature of the threat is singular: it has no multicellular shape of its own and simply imitates the life forms it absorbs. The profusion of identifiable forms, coming from different animal species, organically linked against all cohesion, brings a form of de-familiarization. Thus the autopsy sequence of the dogthing is subverted as far from objectifying the threat, it casts even more doubt as to the true nature of what is seen. Something looks like a skeleton, but it is shapeless and there are also insect-like excrescences in a magma of flesh, eyes and mouths. Rob Bottin completely renews the aesthetic frame of classical representation of the creature, using all kinds of technical devices: makeup, prosthetics, animatronics, hand puppets etc. Norris' entire torso opens on a mouth full of teeth that devours Dr Cooper's arms. From the body surges up a gigantic lump of flesh with thin tentacles and stunted human members. Norris' first head escapes, hides under the desk and reappears with insect-like legs and eyes.

Here the unnameable stems from an excess of analogies with something known rather than an absence of analogy. Horror cannot be denied but can't be defined. The creature is never seen completely and rearranges its physical appearance constantly, according to its current needs. It is thus akin to the Lovecraftian shoggoth depicted as «a congeries of iridescent bubbles» or «multicellular protoplasmic masses able to fashion their tissues as provisional organs». The Thing does not allow conceptualization. Seeing it brings even more confusion, disarray and panic. When it sticks to one specific shape (an animal or a human being), it constitutes an even more horrifying hidden threat, off screen. 
PRINCE OF DARKNESS

An occult, hidden threat is at the heart of Prince of Darkness (1988). The film revolves around the crypt of a church that holds a mysterious container filled with green fluid. When its guardian dies, a priest asks a scientist and his students who are specialized in various fields - molecular biology, quantic physics, mathematics, radiology, but also translation of ancient languages and theology - to inquire about the object and an old book. The cylinder is 7 million years old and contains a form of primordial energy, a kind of anti-God residing in the anti-matter and trying to infiltrate our world by means of mirrors. The film contains various Lovecraftian motifs: an ancient evil which seeks to control the world, occult writings, a sect of threatening beggars reminding of the Cthulhu cult, investigating men of science trying to rationalize a supra-universe, etc. The plot takes up the incipit of «The Call of Cthulhu». The death of an old man leads to frightening disclosures. Evil becomes a material fact and human awareness becomes inevitable when scientific lore blends with occult knowledge.

Evil is apprehended through the medium of science, which makes its nature and manifestations all the more disquieting. The growing presence of insects is explained by the electro-magnetic radiation of the power. They are the sign of an abject progression. First ants on the campus, then within the church, glasses covered with worms. Lastly beggars covered with ants or worms and the scientist serving as a spokesman for the entity. The liquid appears as having a sort of sentience and it re-arranges itself at great speed. We find again the same idea of mutation and contamination. This ancestral evil seeks to liberate itself by possessing bodies and minds and by manipulating objects through telekinesis. The liquid flowing upwards is used by the entity to control the world. Atmospheric phenomena take place and the time frame is subverted. Susan the radiologist, irresistibly drawn to the cylinder, is splashed with the liquid and submitted to the power of the anti-god. Marginal people belonging to a sect «The Brotherhood of Sleep» put a siege around the church and perform ritual murders. Gradually scientists are contaminated, turned into zombies and the remaining ones are confined within a restricted space, a typical Carpenter huis-clos. Knowledge is not only frightening but dangerous since the scientists prove to be eventually responsible for the liberation of Evil. That evil entity condemns both science and religion as is shown in the ominous message it addresses the human community: "You won't be saved by the holy-spirit. You won't be saved by God Plutonium. You won't be saved at all». 
However, thanks to the sacrifice of one student, danger seems to be avoided. Catherine Danforth (Lovecraftian name) plunges through a mirror with Susan whose body has been invested by the anti-god, bringing back the latter to the other side of the mirror. As often with Carpenter, the end remains open. One of the survivors, Brian Marsh, makes a dream where he sees no longer a black shape, but Catherine, the new potential vehicle of the anti-god. Indeed, the fate of humanity seems rather hopeless since the advent of the entity will occur when «the stars are right». The motif of the remote supernova and the sun eclipse take up the cyclic structure that is repeated when Brian Marsh, aware of Catherine's mistake draws his own hand slowly near the mirror surface. This shot repeats in a reversed way that of the entity's hand approaching the limit between the two worlds. The cut to the credits happens just before the contact.

The film gathers varied components of Lovecraft's universe. First the presence of a rationalist inquiry led by a scientist about irrational phenomena and the idea of a secret occult power, sleeping or imprisoned since the depths of time, but surging up in order to take possession of the world again like the Old Ones as described in the Necronomicon. Secondly the presence of a sect that serves this entity as in «The Call of Cthulhu». Carpenter exploits the motif of psychic projection through the dreams of sensitive protagonists (often artists or scientists) as in «The Shadow out of Time» and that of metamorphosis or monstrous mutation. The film also adopts a critical distance towards religion, which denies the true nature of evil and in particular its material character. This is close to Lovecraft's materialist and relativist stance.

\section{In the Mouth of MADNess}

With In the Mouth of Madness ${ }^{5}$ (1995), Carpenter offers a synthesis of Lovecraftian themes, adopting a more radical meta-textual and meta-filmic approach. He highlights the reading process and sacralises the figure of the writer who becomes demiurgic. The film opens on the arrival of John Trent (Sam Neill) the hero at a psychiatric asylum as he is put in a straightjacket and locked up in a padded cell. He receives a mysterious visitor, an unidentifiable black shape who evokes the reading process: «This is not the ending. You haven't read it yet». Most of the film consists of a flashback narrative of Trent, an insurance investigator who tries to find Sutter Cane, a best-selling horror

5 This title conflates two references to Lovecraft: «Mouth» echoes «The Shadow over Innsmouth», «madness» reminds of «At the Mountains of Madness». 
writer who has vanished. Cane has in fact found refuge in Hobb's End, a fictional city, which is the privileged setting of his fiction. When he finally finds Cane, Trent realizes he is also a fictitious character meant to bring to the world Cane's last book, which will cause apocalypse.

The references to Lovecraft are numerous. The titles of Cane's novels: The Thing in the Basement, The Hobb's End Horror are derivative of those of HPL's stories like «The Thing on the Doorstep» or «The Dunwich Horror». Lovecraft also uses fictional cities like Arkham, the fictional double of Providence, or Innsmouth, which like Hobb's End is the backcloth for various forms of hybridization. The hotelkeeper, Mrs Pickman, is a clear reference to «Pickman's Model». She keeps her husband chained behind the bar and eventually turns into a tentacled monster, armed with an axe. In this hotel, Trent finds a strange painting where the characters seem to move within the frame, recalling the animated portrait of Joseph Curwen. Cane's last novel relies on the seminal concept of the return of the Gods as cosmic entities preparing to invade the world. These creatures are first perceived almost subliminally in a flash forward fast edited sequence. Then they mostly remain off screen but are shown again by Cane behind the door that separates reality from fiction. When the door yields under the pressure, the creatures go after Trent through a kind of damp uterine corridor. Their monstrous hybrid morphology explicitly recalls Lovecraftian Cthulhuoid or frogmen creatures.

Sutter Cane's novel also develops the idea of the artist as mediator between men and Gods. In Lovecraft's fiction, the cosmic entities communicate with artists by entering their dreams and suggesting apocalyptic visions as in «The Call of Cthulhu» where Wilcox the delirious sculptor visualizes the sunken city of R'lyeh. In the film, the monsters from outside dictate Cane the contents of his books. Carpenter also introduces the motif of the forbidden book whose reading leads to insanity. While Lovecraft asks Randolph Carter to remember he is dreaming and thus that his adventures were his own creation, Carpenter in the same line throws Trent, his rational alter ego in a story where he becomes aware of his own fictional nature. The film stages a very complex space, both restricted and open on an infinite space and time. The fictitious space of Cane's prophetic literature contaminates Trent's intra-diegetic world. The arrival at Hobb's end, governed by unknown laws, signifies the loss of space landmarks, the circularity of the journey and the dead end because of the deregulation of time. The tunnel-shaped bridge leading to the little town functions like a geographic boarder and is linked with a change of ontological status. Trent and Styles are printed/photographed by a blinding light (a series of 
flashes) and become fictional beings or film reel beings. Cane, a demiurgic writer found refuge in a Black byzantine church (evoking that of «The Whisperer in Darkness») which is described in his novel and also features in the hotel painting, as a hidden image. Linda Styles who surprises Cane typing his manuscript is «printed» by the writer who presses her face on a printing machine in order for her to see/read the truth contained in the pages. Styles sees a series of fast edited images adumbrating the fate of the main characters. When she raises her head, blood runs out of her eyes as if the vision were too intense to bear. When she embraces Cane, the latter mutates into a monstrous octopus-like creature. Linda herself undergoes a transformation process as announced in the proleptic images. Cane tells Trent that all he has been doing is already written in his unpublished last book, In the Mouth of Madness.

Trent is thus not only acted upon, but also conceived by Cane who claims his power, with a wink to René Descartes' cogito: «You are what I write... I think therefore you are». Cane then tears off his own face as if it were a mask, but underneath the mask, there is no flesh but only printed text. Through the ripped off page, a big hole reveals Trent and Styles, on the other side of the printed page, in the long intra-uterine corridor leading to reality. While Trent bends over the rip in the page, Styles reads a very Lovecraftian text, part of Cane's novel: «Trent stood at the edge (...) stared into the illimitable gulf of the unknown, the stygian world, the yawning black beyond».

Abandoning Styles who already knows the end of the novel, Trent flees through the corridor, pursued by the monsters and finds himself out of the village. Back in town, Harglow the publisher tells him that Styles never existed; that the manuscript he destroyed is already published and adapted to the screen. After an ellipsis, we learn that the book has driven people insane. Trent himself, reproducing the earlier act of the homicidal literary agent kills a reader with an axe. It is the end of the flashback and the hero is found again in his psychiatric cell, another Lovecraftian topos. An ellipsis reveals an empty asylum, totally shattered. The radio reveals that a form of collective madness has spread through the country. Trent escapes from the asylum and reaches the town. He finds himself, an ultimate metaleptic shift, in front of a movie palace that screens In the Mouth of Madness, where he (John Trent and not Sam Neill) plays the main part. Trent watches the filmic images we just saw and is seized with a hysterical laughter (a shot already seen previously in flash-forward images). What was projection in the future is now retrospective. The frontier is blurred between written text in the film, fictitious film adapting a fictitious novel and real film containing all other narratives. 
In the Mouth of Madness constitutes an important stage in the symbiosis between Lovecraftian mythology and cinema. Carpenter, using both suggestion and visual exhibition, takes up the idea of a world vaster and stranger than it seems, emphasizing the role of books and artists as mediators and also the function of dreams. Carpenter prolongs the Lovecraftian mythos in a fairly convincing but also partly ironic and parodic way, putting forward man's problematic relation to a reality whose contours are blurred and his potential eradication by superior forces, thus conjuring up a certain idea of outsideness and a genuine sense of wonder. However, Carpenter ultimately highlights the power of fiction, whether textual or filmic.

Filmmakers have used various registers, ranging from stark realism to fantasy. They have staged spectacular transformations, entities surging up from the depths of oceans or from subterranean cities, either real or oneiric. They have coped with varied obsessional themes like physical mutability, contamination, psychic transfer and they have foregrounded iconic objects like the Necronomicon that holds a forbidden knowledge.

However, Lovecraft's tales, based on a rhetoric of the unsayable, offer a resistance to the adaptation process, even at a time when digital images and sophisticated special effects enable a more convincing representation of the settings and the creatures born from his imagination. Relatively few ambitious projects have been carried out over the recent years. We may indeed regret Guillermo del Toro giving up his adaptation of «At the Mountains of Madness». Lovecraft's fiction will nevertheless go on stimulating the creativity of writers, illustrators, music composers, videogame designers, graphic novelists and filmmakers. His imaginary universe has spread into popular culture and various media, but cinema rarely manages to convey a sense of Lovecraft's materialistic, relativistic worldview, what has been called his «cosmic regionalism».

\section{BIBLIOGRAPHY}

Chambost, Christophe (2017): «La vérité sur le cas de Charles Dexter Ward», in Christophe Gelly and Gilles Menegaldo (eds.), Lovecraft au prisme de l'image: littérature, cinéma et arts graphiques, Le Visage vert, Cadillon.

Cixous, Hélène (1972): «Poe re-lu: une poétique du revenir», Critique, 28, pp. 299-327. Houellebece, Michel (2005): H.P. Lovecraft: Against the World, against Life, Believer Books, San Francisco. 
HutcheOn, Linda (2006): A Theory of Adaptation, Routledge, New York.

Joshi, S.T. (1996): H.P. Lovecraft: A Life, Necronomicon Press, West Warwick.

Lovecraft, H.P. (1976): Selected Letters. Vol. V, Arkham House, Sauk City.

- (1991): The Dunwich Horror and Others, Arkham House, Saul City.

Mitchell, Charles P. (2001): The Complete H. P. Lovecraft Filmography, Greenwood Press, Westport.

Petley, Julian (2007): «The Unfilmable? Lovecraft and the Cinema», in Richard J. Hand and Jay McRoy (eds.), Monstrous Adaptations: Generic and Thematic Mutations in Horror Film, Manchester United Press, Manchester, pp. 35-47. <https: / / doi.org/ $10.7765 / \mathrm{mg} / 9781526125439.04>$

WORLAND, Rick (2007): The Horror Film, Blackwell, London. 